\title{
Management education for the nineties
}

\author{
K.B. Hofmeyr \\ School of Business Leadership. University of South Africa, P.O. Box 392. Pretoria 0001, Republic of South Africa
}

\begin{abstract}
Management educalion, and particularly the MBA degree, is facing considerable criticism in the United States and Europe. It is charged with being 100 analytical in its orientation and out of touch with the needs of the business world. Insufficient antention is paid to areas such as people skills, ethics, and leadership. It is also seen a being out of touch with' current trends in business such as the internationalization of business, the trend lowerds an information/service society, and the renewed interest in organizational culture and participative management. In this anicle these criticisms are reviewed as well as the major trends taking place overseas and South African management education is evaluated against these themes. The author also reports on research conducted in South Africa to identify what managers perceive to be the most important challenges which will face this country's managers in the nineties. In the light of this research, recommendations are made for making South African management education more relevant. Business school curricula must be contexualized while strying close to international trends. Business schools must also learn from the criticisms being levelled at mangement education in other parts of the work. They must respond to the demographic trends taking place in Soath Africa and re-define the role of research in management education.
\end{abstract}

\begin{abstract}
Beswursopleiding, veral die MBA-graad, kry sterk kritiek in die Verenigde State en Europa. Dit word beskou s te analities in orientasie asook uit voeling met die eise van die sakewêreld. Daar word nie genoeg aandag geskenk an areas soos mensevaardighede, etiek en leierskap nie. Dit word ook as uit voeling beskou met huidige neigings in die sakewêreld soos die internasionalisering van besigheid, die neiging na 'n inligting/ diensgemeenskap en hernude belangstelling in organisasiekultuur en deelnemende bestuur. In hierdie artikel word die kritiek sowel as die vernaamste rigtings wat oorsee ingeslaan word bespreek en Suid-Afrikaanse bestuursontwikkeling met betrekking lot hierdie onderwerpe word geEvalueer. Die outeur lewer ook verslag oor navorsing wat in Suid-Afrika gedoen is on te bepaal wat besturders se siening is oor die belangrikste uitdagings wat hierdie land se besturrders in die jare negentig in die gesig sal staar. In die lig van hierdie navorsing word anbevelings gemaak om Suid-Afrikaanse bestuursontwikkeling meer relevant te maak. Sakeskool-keerplanne moet saamgestel word on tred te hou met internasionale tendense. Hulle moet ook leer wit die kritiek wa oor bestuursontwikkeling in ander dele van die wêreld uitgespreek word en moet reageer op die demografiese neigings wat in Suid-Afrika plaasvind en die rol van navorsing in bestuursontwikkeling herdefinieler.
\end{abstract}

\section{introduction}

A feature of the South African condition is that considerable effort goes into forecasting future scenarios and determining what the options are for the country. Futures research has become a growth industry and has provided some thought-provoking analyses of the general trends and challenges. What is needed now is a more narrowly focussed examination of specific areas within the broader scope of this research. For example, there have been numerous analyses of the future human resource requirements of the economy, and the critical shortage of skilled and managerial personnel has been well documented. What has not had enough attention has been the research and analysis to develop strategies to moet this challenge. Undoubtedly education will play a key role in the development of our human resources and this article will concentrate on an area within the broader educational field, namely the education of managers.

My general purpose is to identify the major challenges facing management education and propose appropriale strategies to meet them. I want to start by reviewing international trends in management education and then focus on the position in South Africa. I will survey some of the problems facing commerce and industry in the nineties and also report on a study I undertook recently which throws light on managers' perceptions of future challenges. The international trends and the local data will then be used to suggest some strategies for business schools in the future.

\section{American and European experience in management education}

Challenges facing management education are not confined to South Africa. In the United States of America (USA) and in Europe many questions are being asked about the effectiveness and relevance of management education. The main trends in the debate can be summarised as follows:

\section{American experience}

Since the early sixties in the United States the Master of Business Administration (MBA) has been an important part of the young high-flier's preparation for success in business. In 1965 some 5000 students graduated with MBAs. In 1988 over 70000 MBAs were awarded. Some of the gloss, however, seems to be coming off this once highly-preferred degree. On the one hand there are now relatively more MBAs in circulation and on the other serious questions are being raised about the degree and its appropriateness in the late eighties and early nineties.

These concerns and the stock market crash in 1987 resulted in the class of 1988 receiving only about half as many job offers as its predecessors, and professors at some American business schools are already talking about an MBA-glut (The Economist, July 1989).

Criticism of the MBA in the United States has centred 
on the relevance of the traditional MBA in a rapidly changing business environment. According to Business Week (November 1988, 84) critics in commerce and industry argue that business schools turn out 'greedy, overambitious people with little more than basic financial skills. Once in the business world, they focus their time and energy on financial activities - not on effectively leading people, making better products, or assuring manufacturing quality.' Since the seventies and early eighties the focus in business schools has been on analytical problem solving, but more recently numerous articles and reports have been questioning the reliance on analytical methods as the core of the MBA curriculum. Leavitt (1988, 3) expresses concern about the lack of balance in management education when he says that '...we have developed a weird, almost unimaginable design for MBA level education for management. We then lay it upon well proportioned young men and women, distorting them (when we are unlucky enough to succeed) into critters with lopsided brains, miniscule hearts and shrunken souls'. He believes that business schools need to teach students not just to think about management (that is, how to solve problems intellectually) but also how to actually manage (how to pathfind and implement in addition to solving problems).

Consistent criticism of management education in the United States prompted the American Assembly of Collegiate Schools of Business (AACSB) to commission a strategic study of the future of management in the United States. The results of this three-year study were published in 1988 in a report entitled 'Management Education and Development: Drift or Thrust into the 21 st Century' by Porter and McKibbin. The report warned that success has tumed American business schools into complacent, self-satisfied institutions that are in danger of becoming irrelevant. Among the most important findings were the following:

Whereas the USA corporate world recognised the analytical skills, motivation and content-area knowledge of business graduates, they would like to see more 'realistic, practical, hands-on' education with greater emphasis on the development of people skills such as leadership and interpersonal skills;

Corporate respondents supported the idea that research should be one of the major missions of business schools, but claimed that they paid relatively little attention to the findings of the research;

Both academics and corporate managers agree that business schools, and their faculty, do not interact enough with the business community.

To prevent management education activities from drifting into the 21 st century the authors urged business schools and their leaders to engage in more rigorous strategic planning 'to prepare for looming changes in which business education will be operating in the next ten to fifteen years' (p. 311). They noted that while business schools include strategic planning as a subject for their students, few schools engage in significant longterm planning.
Their research highlighted six areas which need more attention in the curriculum:

1. Breadth. Business schools should emphasise the importance of a broad education. The MBA has to continue to provide education in 'general management' and students need a solid grounding in the management functions such as marketing, finance and accounting, human resources management, and business policy.

2. The external environment of organisations. A better balance is required between the attention focused on the operational effectiveness of firms - the 'internal' environment - and outside influences such as governmental relations, societal trends, and intemational developments.

3. The international dimension. A more thorough and rigorous global perspective should be incorporated in all aspects of the curriculum.

4. The information/service society. An information orientation needs to be incorporated throughout the curriculum. This is because the American economy has changed from one based on industry to one based on service and information. More people are now employed in the service sector of the economy than in any other.

5. Cross-functional integration. More attention should be given to the synthesis and integration of specialized functional areas in the curriculum, rather than treating them as separate entities.

5. People skills. Business schools had to find ways to develop stronger leadership and interpersonal skills in their students.

In a more limited study undertaken by the Graduate School of Camegie Mellon, the managers surveyed showed the same concern for the long-range fundamental business issues and less concem for the short-term financially oriented issues of the $80 \mathrm{~s}$. Respondents believed that the most promising means of competing effectively locally and internationally in the next decade would be through the implementation and re-emphasis of practical business measures such as improving productivity or service quality, listening to and anticipating customer needs, and using technology to competitive advantage. Hanley (1986), for example, advocates that what is important is for MBA graduates to have the ability to transfer their knowledge and relate it to the real situation.

In addition to specific recommendations which are being made to improve the MBA curriculum, there are changes taking place in commerce and industry in the USA which will also influence management education.

USA business is very concerned about its international competitiveness and the complexity and importance of the global environment is emphasised throughout the literature. Frequent mention is made of the need to incorporate cross-cultural and comparative management in business school curricula. O'Neal (1985) notes that expansion into worldwide markets requires an effective grasp and understanding of other values, cultures and political systems. As Fortune magazine (July 19, 1989, 58) puts it, not entirely light-heartedly, 'The MBA of the 
future should speak a foreign language and be intimate with a foreign culture, Japanese preferred in both cases'.

The American literature on business trends stresses the fact that companies are facing a period of fundamental change which will involve significant institutional transformation. Organisations are becoming increasingly information intensive as the country develops from an industrial society to an information society. This means that managers will require good oral and written communication skills. They will also need to be computer literate and be able to analyse and summarise data.

There is also a noticeable trend towards decentralisation in organisations. The implication of this is that managers must be effective in communicating with and controlling many areas. Managers must understand and manage the 'linkages' between small, autonomous yet interdependent work units, and since decentralisation requires management of smaller groups, managers need to be good negotiators and team builders. Decentralisation has also led to an increase in entrepreneurial activity because the executive now manages a strategic or small business unit and has a large degree of autonomy.

Some debate is taking place about the role of middle management in organisations and whether computers and other changes may make middle managers redundant. Drucker (1988, 45), for example, forecasts that 'The typical large business 20 years hence will have fewer than half the levels of management of its counterpart today and no more than a third the managers'. On the other hand, Porter and McKibbin (1988) note that there is little systematic evidence that this trend is happening yet on a major scale.

Nelton (1984) predicts that managers increasingly will have to deal with a wide range of social permutations ranging from restructuring of basic industries and displacement of workers, to a larger proportion of women in the workforce, to shifts in lifestyle and greater numbers of people working at home using personal computers. In his view society is entering a period of continuing and significant change and managers will need flexibility to deal with it. Taylor (1983) notes that the real challenge is to help managers to cope with the increasing rate of change, uncertainty and insecurity, and how to prevent their skills from becoming obsolete.

The very nature of organisations is changing. They are becoming less hierarchical and more participative with less reliance on 'top down' autocratic authority. This has led to a renewed interest in the concepts of company culture and employee commitment. American business people and academics are stressing the importance of 'organisational renewal' and an appropriate organisational philosophy and culture. It is not sufficient to run a tight ship: the manager has to obtain the wholehearted co-pperation and commitment of the workforce. Zenger (1988) notes that the historic tendency has been for management to focus on control as its main emphasis. However there has been a significant shift in the last five years towards an emphasis on obtaining commitment from all employees: 'It would appear that executives have finally heard and believed this message and at long last are willing to change their management practices to give greater opportunities for employee involvement' (Zenger, 1988, 2). An important phrase in the USA business vocabulary now is "employee empowerment'.

\section{European experience}

Whereas the demand for MBAs in America is levelling off, by contrast, Europe seems to be warming to the idea of management education. According to The Economist (July 1989), of 45 European business schools surveyed recently, 18 were less than five years old. However, in Europe an MBA does not seem to be as important a part of a young high-flier's preparations for success as it is in America. This is reflected in a recent survey of 200 major UK organisations reported by Thomas (1989). These organisations indicated that in-company courses were often seen as more effective than MBA programmes which were believed to be too long, inflexible, abstract and relatively poor value for money. (It is interesting to note that Japan is also becoming more interested in the MBA although there are still relatively few MBAs, some 2500 , most of whom have obtained their degrees in America. But the degree is not as important for success in Japan as it has been in the USA - a situation similar to the European one.)

In Europe the major structural change will be the opening up of the European market in 1992. Challenges include the organisational restructuring and repositioning needed to deal with this event, the need to keep organisations competitive on the world market, and finding a balance between the necessities of a manufacturing and production philosophy contrasted with those characterising a service and information society.

Van Gils (1988) highlights some of the issues facing European business schools:

1. The extent to which they can keep up with the increasing competition from independent and private institutions.

2. The necessity for universities to attract and develop good management teachers, given the present shortage.

3. Necessary changes in the curriculum in relation to major questions within business.

Van Gils also points out that there is no fundamental European approach towards management education and no explicit European identity in this field. There is 100 much reliance placed on American models and theories that do not fit European culture. He believes also that there are 100 many weaknesses in the American business school programmes that the Europeans have copied. He lists these as being:

* Overemphasis on analytical skills.

* Overuse of the case study method.

* Narrow focus on functional areas, neglecting integration, synthesis, and a comprehensive approach.

* Inaccessibility of research results. 
* Stress on teaching instead of learning.

* Partial neglect of communication and social skills.

Many of the European business schools have difficulty attracting high quality faculty, partly because of the gap between university and commercial salaries and benefits, and because the Ph.D requirement is a barrier to entry. Van Gils also believes that there is a lack of emphasis on, and facilities for 'teaching the teachers'. As a result the university-based business schools are losing their share of the business training and development market. They are tom between an academic reputation and business acceptance, whereas private management training institutions are in a better position since they are more flexible.

The European schools have also recognised the need to develop the 'softer' skills, such as communication and social skills. The Lancaster Report (Easterby-Smith and Tanton, 1988), for example notes that since the 1950s the USA debate has led to a stronger emphasis on management as a science which should be based on quantitative analysis. However in the late 1980 s there is a growing interest in human resource development, ethics in business, and transformational management. In Europe in a transitional phase, the development of these skills and qualities is vital, but there is a concem that the eagerness to copy the American formula may have led to the neglect of the 'people skills'.

To summarise then: in the USA serious questions are being asked about the focus and content of business school curricula. The consensus is that more attention needs to be given to issues such as the international context, the external environment of the organisation, the information/service society, practical business skills, and people skills in order to respond to the trends in American society and the international economy. In addition, there are structural changes taking place in business such as decentralisation, different labour structures, altered working patterns, and new organisational cultures that must be reflected in MBA courses. The review of European trends also indicates concern about the relevance of management education in a changing context as well as the extent to which European schools mindlessly copy the USA model. Practical issues were raised such as the need to assist business to prepare for 1992, the need for people skills, the importance of good management teachers, and the threat posed by private management training institutions.

\section{Challenges facing management education in South Africa}

It is clear that management education in the USA and Europe is undergoing considerable re-evaluation and soul searching. Questions are being asked about its appropriateness to the needs of these societies as they enter the nineties. Given the challenges faced by South African business, management education in this country also needs to be asking questions about its relevance and its effectiveness. To be relevant, management education has to address the challenges of the present and the future.

\section{The South African context}

What are some of the features of our context which should be considered if we are to design relevant management education? I will review briefly some key issues in the political, economic, social and educational contexts.

There is no doubt that politics and political change will be important features of our lives in the next ten years. National and international pressures and tensions will continue as the country looks for legitimate and democratic political structures. The business world will not be able to isolate itself from the political environment and increasingly companies and organisations will need to consider the implications of political developments. They also will have to decide what their role should be in the change process. As Peter Searle, chairman of Volkswagen South Africa wrote recently, 'The primary role of business is business and not politics or matters of a socio-political nature. However, in the circumstances in which we find ourselves today, it is not possible to ignore political and socio-political factors...' (Sunday Times, August 13, 1989, 18).

Business has become more involved in addressing these factors. According to Lee and Buntman (1989), since 1987 business has developed a sustained interest in influencing public policy which belies the conventional theory that business interest moves in cycles - high in times of economic and political hardship and low when times get better. They observe that within corporations there have now appeared individuals and whole departments dedicated to policy analysis. Universities receive funds to research policy issues, advise, and publish. And privately funded, policy-dedicated institutes are beginning to appear. Clearly, politics and business are inextricably linked.

The economic reality is a sobering one. Terblanche (1989) argues that the economy is still on the decline that started in 1974 after the oil crisis. Our average growth rate has been less than two per cent annually and per capita income has declined by 0,5 per cent annually and by more than one per cent since 1981 . He observes that the economy would have $t o$ grow by at least five per cent to accommodate the 350,000 (or more) people that will enter the labour force annually during the nineties, otherwise large-scale unemployment is inevitable. Furthermore, there is a grave shortage of skilled and management people in the economy. It is estimated, for example, that job openings at the skilled manpower level will exceed supply by no less than half a million in the next decade. During the nineties there is likely to be shortfall of at least 100,000 people in the top management category and a shortage of 400,000 professional and technical people (Hersov, 1989).

Another structural aspect of the economy is what Sunter (1987) calls its 'dual-logic' nature in which a 
relatively sophisticated economy exists alongside a much less developed, informal sector. The informal sector is growing at approximately 15 per cent per annum and has to be recognised as an increasingly important component in our economy especially as a provider of entrepreneurial opportunities and employment. Business and management skills are desperately needed in both sectors and management education has a key role to play in providing these.

Social factors and demographic trends are powerful forces in our environment. Some 3500 children are bom in South Africa every day. Nine out of ten are black. At present whites comprise approximately $14,4 \%$ of the total population, by 2000 it will be $12,2 \%$. South Africa's urban population was 15,2 million in 1980; it will double to about 30 million by the year 2000 . Eighty six per cent of the people joining the labour force during the nineties will be black, coloured, or Asian (Manning, 1988). The country's harsh economic, demographic and social factors make up what Schlemmer and his co-researchers (1989, 157) call our 'social economy' and they describe it as the total of 'subtle distorting effects, advantages and disabilities which are built into the social fabric'.

The interplay of political, social and economic factors has led to gross inequalities in our society. The Second Camegie Inquiry into Poverty and Development in Southem Africa (1989) highlighted the inequality between the country's rich and its poor. This ratio, known as a Gini coefficient, compared the relative poverty in 57 countries and found South Africa to have the worst rating. The report investigates issues such as rural underdevelopment, lack of access to energy sources and water, malnutrition and other symptoms of poverty such as overcrowding, illiteracy, and unemployment. According to Operation Hunger, as many as 1,5 million people are on the verge of starvation. Some rural hospitals report as many as 60 hunger-related deaths a month. Current black unemployment could range between five and six million (Van Nieuwkerk, 1989). This 'darker side' of our society is another feature of the South African context which has to be confronted by the private sector. Business is seen by many, especially in black communities, as an accomplice of apartheid, and capitalism has become discredited. Consequently, to undo its negative image, business will have to be seen to be tackling the problem of redistributing wealth, power and opportunities while it is engaged in generating wealth.

There are other aspects which deserve attention, but I would like to highlight just one further issue, namely the education crisis. The statistics paint a very gloomy picture: fifty one per cent of our adult population is illiterate (compared with one per cent in Japan and 13 per cent in America); fewer than ten African pupils, and fewer that twenty coloured pupils out of every 100 who start school, matriculate; 87\% of African teachers are underqualified; of the thousands who matriculate each year only some 500-800 African pupils have higher grade maths and science. On the qualitative side, since 1976 many black schools have been in turmoil with frequent boycotts, violence and in some cases an almost total breakdown of any meaningful education and the will to learn. There is talk of 'lost generations' of black school-goers (Hofmeyr, 1989). If Sunter (1987) is correct that a 'winning nation' is built on a foundation of sound education, and especially on a uniformly high standard of education throughout the whole population, this area presents us with enormous challenges.

These realities: political change, economic decline, powerful social forces, gross inequality, and an education crisis represent a context which has to influence management education. Business schools and other institutions have to be sensitive to this environment as they design their curricula. To maintain a comfortable, arms-length distance from these realities is to risk being irrelevant. The same message was clear in the review of the debate in the USA and Europe. These countries are also looking at their own changing environments and saying. 'What do we have to do; how do we have to change in order to be relevant?'

\section{Managers' perceptions of challenges}

Against the background of the South African environment described above, I was interested to try to find out how managers perceive the challenges facing them in the future. As part of a research investigation I asked a sample of 240 middle managers working in a cross section of functions and industries throughout the country what they thought would be the major challenges faced by management in the next five years. This was limited, qualitative research and cannot be taken as the final word on the subject, but it does provide some interesting pointers for management education. The results were as follows:

Forty eight per cent of the total responses dealt with perceived challenges related to human resources management. This included, in order of priority, industrial relations challenges, the need for increased productivity, dealing with the skills shortage, training managing the black/white interface, and 'black advancement'.

Twenty eight per cent of the responses referred to economic challenges. Again in order of perceived importance were: the need for cost control, dealing with the effects of sanctions, the need to compete in the world markets, and job creation.

The next challenge identified by $11 \%$ of the responses focused on political issues. Issues highlighted here were the fluid political climate, the need to adapt to political and social changes, the impact of politics on labour relations and business in general, the conflict between first and third world orientations, and the challenges of a 'post apartheid society'.

Technological issues were mentioned in $6 \%$ of the responses. These included keeping abreast with new technology, the challenge of information technology, technical education, and the need for computer literacy.

Five percent of the responses dealt with management styles. Here mention was made of participative management and employee involvement, the 
management of change, the need for vision, and the need for a unique South African management style.

Included in the study was a question which asked what skills, knowledge, and attitudes would be required to deal effectively with these challenges. The most important skills identified were, in order of perceived importance:

'People skills'

Negotiating skills

Human relations/interpersonal skills

Industrial relations skills

Marketing skills

Strategic planning skills

Financial management skills

Analytical skills

Technical skills

Important areas where knowledge would be needed were:

Financial management

Broad general grounding in business

Knowledge of different cultures

Technical knowledge

Political awareness

Micro and macro economics

Attitudes required in the future are likely to be:

Willingness to change/innovativeness

Vision/faith in the future/optimism

Move away from discrimination and racial prejudice

Open-mindedness

Need for entrepreneurial spirit

Development of a sense of 'social responsibility'

Some of the perceived challenges highlighted in this research are similar to those identified in the USA. Human resources management, information technology, computer literacy, participative management, and entrepreneurship are common themes. People skills, human relations, and negotiation were also emphasised in the USA and European literature. However, the perceived South African challenges and the way in which they are described present a significantly different overall picture of what managers must be able to do and hence what is needed in our management education. Industrial relations, productivity, job creation, the emphasis given to political challenges, the references to issues of race and culture and the need for attitudinal changes are what differentiate our priorities from those of the USA.

To the extent that issues such as these are not being addressed in our management education in the nineties. business schools may lack relevance. Rigid adherence to American curricula and formulae will not help us meet South Africa's challenges. Nevertheless, the areas of common and overlapping challenges suggest that although we must not slavishly follow Western models, we cannot ignore that body of experience and international trends. While we study our own context, we also have to take note of the intemational context. Changes in the intemational economy, technological advances, political alignments, and the effects of sanctions and disinvestment on South Africa will influence business in this country. South Africa is part of the global village.

\section{Implications for management education In South Africa}

The international debate, the review of some of the issues confronting business and the country as a whole, and my research provide a framework within which to examine management education in South Africa and offer some suggestions.

\section{Human resource issues}

Almost 50 per cent of the responses in my research referred to human resource issues and it seems that the nineties will be characterised by challenges relating to the skills shortage, race relations in the workplace, employee advancement and productivity. An immediate implication would be that these issues should be addressed more directly in our courses on human resources management and organisational behaviour. Our management education has to prepare future managers to understand these issues and to be able to place them in the context of a society which has the technical and structural problems which were reviewed earlier.

In terms of the skills which will be needed in the future, the people skills were emphasised in my research. This was also a clear message arising from the review of the trends in the USA and Europe. It seems that to be relevant, management education in South Africa will have to pay more attention in its curriculum to the management of people and the development of human relations and interpersonal skills. As Godsell $(1988,6)$ has observed, 'Different dimensions of economic society achieve critical importance at different moments in history. In earlier times in South Africa critical skills were those of the engineer. In the pioneer phase of South Africa's industrialisation it was the skills of the engineer, the geologist, the fitter and turner which were at the cutting edge of economic activity. In the later consolidation phase (roughly from the second world war on) financial skills became of paramount importance. Business growth demanded expert management of finance. There is every indication that the last decade of this century will see 'people management' skills achieve a pre-eminent position in management.

\section{Organisational change}

Business is undergoing fundamental changes internationally and locally and management education has to adapt and respond accordingly.

The trend towards participative management in the USA which was also identified in my research will be a major feature of South African businesses as they try to involve all employees in a more meaningful commitment to their organisations. We have to learn all we can in this area from other countries, perhaps particularly from Japan. If communalism and co-operation are features of the employee workforce in this country, then teams, quality circles, consensus decision-making and other features of the Japanese style of management seem more appropriate than Western, individually-oriented approaches. New management styles 
and culture changes would require the vision, the flexibility, the leadership, the willingness to change, and the new attitudes which emerged in my survey as prime issues for management education. These qualities are what Leavitt calls the 'soft front end of the managing process' which we have neglected in our management education to date. He argues that 'It is time to seed a new generation of more diverse, more innovative and more visionary managers' $(1988,20)$.

The finding by Hanley (1986), noted earlier in the review of the international literature, namely that MBAs must be able to transfer their knowledge and relate it to the real situation, seems particularly important in the local context where there is a shortage of managers and a hands-on style is necessary. If MBA and MBL students are taught to approach management in a detached, analytical, cautious manner this could have serious consequences if the issues faced by South African managers are complex, intense and often emotional. As Harari and Beaty (1985) argue, our managers need intuition, commitment, flexibility, and a willingness to experiment.

Another institutional change, the trend towards decentralisation in the USA, did not emerge in my own research, but it is a trend which is starting to be seen in this country and will continue. Business school courses will have to address the entrepreneurial skills and thinking that will be required by decentralised business units.

\section{Curriculum change}

An underlying theme of this paper has been the observation that what is taught on an MBA or MBL has to be contextualised. As we have seen, the Europeans are concemed about the tendency to follow the USA model in terms of curriculum, methodology and textbooks. My research has identified challenges which are specifically South African. No American text or case study or approach can capture fully the context and nature of the South African challenges. Amongst other things, this means that the traditional subjects such as marketing, operations management, human resources management, finance and accounting, need to be tied much more closely to the South African context. Techniques of operations management, theories of organisational behaviour, and case studies on marketing need to be linked constantly to local constraints and opportunities. Due recognition has to be given, for example, to the fact that a large part of our economy is a third world one with unique challenges often not even referred to in traditional management texts.

Most of the textbooks used in our business schools, and many of the articles and case studies, are written by American academics. This material may cover theories which are universally applicable, but when the text applies the theory to problems which American business people have to face, these often lack relevance for a South African audience. As Moulder $(1989,77)$ points out, '... even though South African business people are grappling with questions about affirmative action and corporate social responsibility, the social, political, ideological, educational and economic environments in which they are doing so are vastly different from the ones in which Americans have to answer these questions.'
My research highlighted some South African issues which could be incorporated in the curriculum. Many of these are qualitative issues which suggest that our curriculum will have to go beyond simply imparting knowledge about business concepts and processes. Political challenges probably rank higher in South Africa than they would in many other countries. It seems therefore that South African managers need to be exposed more deliberately during their management education to political issues: the role of business in politics; discussions on different socio-political and economic systems; debates on issues such as sanctions and disinvestment. These would have the effect of making potential managers more politically aware as they prepare to take up leadership positions in business in the future. Again Godsell $(1988,7)$ comments: 'Both business and labour are now inextricably caught up in broad political processes, and both good information, as well as conceptual understanding will be required in these areas.'

Reference also was made in my research to the need for 'knowledge of other cultures'. Probably management courses should include an input on sociological issues such as race, class and culture and revisionist interpretations of the history of whites and blacks in South Africa and Africa, as Harari and Beaty (1985) have suggested.

An important finding in the research was the need for attitudinal change, the need to move away from discrimination, and the need for tolerance and openmindedness. If one purpose of management education in this country is to prepare students for institutional and societal change then we will have to pay attention to change processes, how change takes place, and how it is resisted.

Values and ethical considerations underlie attitudes. It seems that managers, particularly South African managers, need to understand what values are, gain an insight into the values which determine their own behaviour, and be able to compare and contrast their values with those of others. In terms of the current debate they need to have the opportunity to think through different and often competing value systems and related concepts such as liberty, justice, equality, rights, privileges, power, competition, and co-operation. Similarly, an understanding of business ethics linked to issues such as corporate social responsibility and affirmative action would also be important content for a relevant curriculum (Moulder, 1989). We need to suggest new conceptual frameworks to students and encourage flexible, critical thinking so that we can find new ways to solve problems and learn that we do not have to do things the way we have always done them in the past!

We must also re-look at our teaching/learning strategies. 'Talk and chalk' still predominate. Learning has to be made more active, rather than passive. The education crisis and the altemative education movement have made us aware of the need to change our methods in order to develop independent, self-directed, critical thinkers.

One of the ways we can assist students to deal with the more qualitative dimensions of our courses is to make use of experiential learning such as games, debates, and simulation exercises which would allow students to learn about stereotypes, attitudes, values and concepts in a personal and practical rather than an academic way. 
New technologies are available such as computer assisted learning, programmed instruction, and peer-group learning. Distance leaming is the fastest-growing trend in tertiary education in this country and institutions in this field must constantly improve their distance learning methods. To do this they will have to keep up to date with overseas developments. Countries like the United Kingdom are making new advances in this field. We can learn from their emphasis on student-lecturer contact, the nature and quality of swdy material, and the use of video, audio cassette and other technologies.

If management educators have to do more than convey knowledge then more attention has to be paid to their development as teachers. The problems of attracting and retaining good academics in Europe and the concern about developing effective management teachers apply equally here in a context where there is a general and grave shortage of adequately qualified teachers in all sectors of education. The lack of emphasis on, and facilities for 'teaching the teachers' which is a concern in Europe, should also concern us.

Many of the comments I have made here have to do with contextualising our management education: responding to our own challenges and trends and not simply replicating an American model. I want to caution, however, that there has to be a balance between South Africanising our curriculum and staying close to developments in the intemational business scene. The increasing globalisation of business cannot be ignored. Unfortunately just as the world is becoming smaller, so South Africa is becoming more isolated. Although the academic boycott is making this increasingly difficult, business school academics should make a point of reading the international literature, networking with overseas academics, visiting, and where possible working in other countries. In particular we need to break away from a fixation on Western models and instead investigate what the East and the developing world can teach us.

\section{'Outreach' initiatives}

The growth of the informal sector of the economy, the need for entrepreneurial skills and job creation, and the problems of poverty and inequality which were noted earlier point to the need for 'outreach' initiatives in our business schools. Scarce resources must be maximised and the management skills which can be developed by business schools are in short supply. Management skills are required not only in the business world. They are needed in communities, in the educational field, in hospitals, in rural areas, in the informal sector. Whether through research, or by running management training courses, or by assisting small businesses, or by involvement in community development, business schools must make a contribution to solving this problem. The trend towards community outreach is already reflected in the establishment of institutes such as the Centre for Developing Business at the Wits Graduate School of Business. The South African business school cannot become isolated on a first world island.

\section{Student profile}

Demographic trends and the education crisis highlighted earlier present some of the greatest challenges for management education. Apart from the content of its courses, for South African management education to be relevant, it has to recognise demographic forces and their implications. The country cannot rely almost entirely on the white population for its managerial talent as it has done in the past. It also has to make better use of the women in the workforce and attract more women into commerce and industry. In the . United States $32 \%$ of the executive jobs are occupied by women compared with approximately $8 \%$ in this country.

Management education has to play its part in assisting black, coloured, Asian, and female employees, to succeed in management. More effort has to be made to enrol people in these categories into management programmes and to improve pass rates.

Given the poor success rate of black students in particular, attention may have to be given to 'academic support' of some kind. The background, experience, and inferior education suffered by most black students puts them at a severe disadvantage and these students require additional tuition in key subjects as well as assistance with skills learning, critical thinking and English language usage. It should be noted that academic support should not be reserved for blacks only because increasing numbers of white students also need help. Approximately $40 \%$ to $50 \%$ of the students participating in academic programmes at the universities of the Witwatersrand, Cape Town, Natal and Rhodes are white students (Hofmeyr and Spence, 1989). The education crisis means simply that we cannot take for granted that white and black students have a body of knowledge, skills and concepts that adequately prepares them for success in tertiary education or in the workplace and therefore academic support will be needed on an expanding scale.

\section{Research}

The need to South Africanise management education points to another area which requires more attention than it has received in the past, namely research. Business schools need faculty who are on the cutting edge in their fields, doing research that will result in innovative course development and assist in corporate decision-making. There are numerous South African challenges and problems which require indepth research, some of which I have referred to: job creation, productivity improvement, management information, organisational culture. More research has to be undertaken by the business schools. There is a shortage of relevant, action-orientated publications, working papers, and reports. Research is sometimes regarded as a 'poor relation' when compared with other demands at business schools.

While there is a clear need for research here, concern expressed about useful research in the USA and Europe should be noted. In the USA too many academics are publishing research which may be of interest to their colleagues in academia, but which are of little value to people in business. Allio (1985) contends that in the USA most new developments in management theory and practice come from corporations and consultants. In Europe, Van Gils (1989) refers to the 'inaccessibility of research results'. The effective utilisation and dissemination of research findings is obviously of major importance. 
One role of a business school is to pick up the signals from the trends and issues in the business community and then use its experience to undertake the necessary analysis and research to find new directions and solutions. Research is staning to become a more important focus at business schools as the new research and development institutes like the Centre for Policy Studies at the Wits Business School and the Centre for African Management at the University of Cape Town indicate. These trends should be encouraged and research efforts rewarded. Consulting work undertaken by our faculty can provide a rich source of data for publications. The fact that our business school has part-time students who are practising managers means that we have a pool of respondents for attitudinal and other research, as well as large numbers of students who can conduct supervised, practicallyoriented research to feed into the business school and the wider society.

The list of implications for business schools is a fairly daunting one: emphasising human resource skills, anticipating organisational changes, redesigning the curriculum, reaching out to communities, changing enrolment patterns and undertaking useful research. As a whole they indicate that business schools will have to take up the challenge of socio-economic development and sociopolitical change. To do so they will have to become involved in considerable re-thinking and restructuring, but I believe this will be vital if business schools are going to make a meaningful contribution to a post-apartheid future.

\section{Conclusion}

Business schools should be wary of 'resting on their laurels'. The complacency suspected of the USA business schools has raised serious questions about their relevance, while in Europe business schools face real competition from private management training institutions and consultants. In South Africa, the future of university-based business schools is by no means guaranteed if they are not willing to change and adapt.

South African management education and particularly the MBA or MBL should not be a clone of the American model. We should be preparing managers to be successful in South Africa, not in America or Europe. Consequently, there is a need to be more sensitive to South Africa's political, social, economic and educational contexts in the design of our courses and programmes. Curricula have to be grounded in the realities of our environment or business schools will become part of the problem, not the solution. However, we cannot ignore intemational trends, debates, and developments. These should be monitored and their implications incorporated into our curricula where appropriate. The need to both contextualise and universalise our management education has been a main theme of this article.

Finally, to retum to a point that was made in the review of trends in the USA, business schools teach strategic planning and management skills, but to be effective they have to practise what they preach. A South African business school needs to develop an appropriate vision and values for South Africa in the $1990 \mathrm{~s}$, and translate them into practice. If it is driven by a relevant mission, it will be strategically positioned in a changing society. To engage in such planning will be essential if business schools are to fulfil their potential to contribute to positive change. Their role is crucial because if there is one thing on which all sides of the political spectrum agree, it is the need to develop an adequate supply of competent managers to take South Africa into the twenty-first century. This is the challenge facing management education in the nineties.

\section{References}

Allio, RJ. 1985. Executive retraining: the obsolescent MBA. Bus. and Soc. Rev.

Are US managers prepared for the 1990 s global challenge? GSIA Update, Jan., 1989, Vol. 1, 1.

B-schools get global vision. Fortune, July 17, 1989, p.58.

Drucker, P.F. 1988. The coming of the new organization.

Harv. Bus. Rev., January/February.

Easterby-Smith, M. \& Tanton, M. 1988. Strategies and faculty development in business schools and management developmens institutions: an international study. University of Lancaster, School of Management and Organizational Sciences.

Godsell, R.M. 1989. The role of the human resources manager in South Africa in the 1990s. IPM Journal, Vol. 6, 9.

Hanley, M. MBA - The fast route to success? Dasa Management.

Harari, O., \& Beaty, D.T. 1986. Africanizing the South African MBA: a way of avoiding self-delusion. S. Afr.J. Bus. Manage., June, Vol. 17, 1.

Hersov, B. 1989. Economy can be boosted. Rhodes Newsletter, Graduation Supplement, June.

Hofmeyr, J.M. 1989. Equalising educational opportunities. S. Afr. J. Labour Relations, June.

Hofmeyr, J.M. \& Spence, R.J.B. 1989. Bridges to the future. Optima,

Leavith, H.J. 1988. On teaching what we haven't taught. Unpublished paper. Graduate School of Business, Stanford University, August.

Lee, R. 1989. The cracks widen. Leadership. July.

Lee, R, \& Buntman, F. 1989. Limousine lizard and the taxi proleteriate. In: Policy perspectives: South Africa at the end of the eighties. Centre for Policy Studies. Graduate School of Business, University of the Witwatersrand.

Manning, A.D. 1988. The new age strategist. Johannesburg: Southern Book Publishers.

Moulder, J. 1989. Towards a new curriculum for business ethics: exploring questions about values and wealth in a South African MBA programme. S. Afr. J. Phil., Vol. 8, 2.

Nelton, S. 1984. Molding managers for the tests of tomorrow. Nation's Business, April.

O'Neal, M.A. 1985. Managerial skills and values - for today and tomorrow. Personnel, July.

Porter, L.W. \& McKibbin, L.E. 1988. Management education and development: drifi or thrust into the 21st cenumy? New Jersey: MoGraw-Hill.

Poverty - South Africa's shame. The Argus, Jan. 24, 1989. 
Schlemmer, L., Stack, L., Van Dyk, H., \& Berkow, C. 1989. South Africa's ideological football. In: Policy perspectives: South Africa at the end of the eighties. Centre for Policy Studies. Graduate School of Business, University of the Witwatersrand.

Searle, P. 1989. Is'nt this what we should expect from business? Sunday Times, August 13.

Sunter, C. 1987. The world and South Africa in the 1990s. Cape Town: Human, Rousseau Tafelberg.

Taylor, B. 1983. Management training and development in the 1980s. In B. Taylor \& G. Lippitt (Eds.) Management development and training handbook. England: McGrawHill.

Terblanche, S. 1989. SA economy still on the decline. Democracy in Action, April.

To MBA or not to MBA. The Economist, July 8, 1989, p.70. Van Gils, M. 1989. Management education: the challenge of the future. Int. Manage. Develop. J., 1.

Van Nieuwkerk, A. 1989. Selling the big lie. Democracy in Action, July.

Where the business schools aren't doing their homework. Bus. Week, Nov., Vol. 28, 1988.

Zenger, J.H. 1988. Training in the $90^{\prime}$ s. Unpublished paper. 